\title{
Clientele Satisfaction towards the Public-Private Partnership Extension Model Introduced for Technology Dissemination in Tea Smallholding Sector in Sri Lanka
}

\author{
M.K.S.L.D. Amarathunga*, W.A.D.P. Wanigasundera ${ }^{1}$ and M. Wijeratne ${ }^{2}$ \\ Postgraduate Institute of Agriculture \\ University of Peradeniya \\ Sri Lanka
}

\begin{abstract}
This empirical study aims to explore the potentials of a public-private partnership (PPP) extension model by appraising the partners' willingness for such an extension model for effective transfer of technologies as a remedy to fill the gap in the extension service to tea smallholders in Sri Lanka. By assessing its strengths and weaknesses using opinions of key stakeholders, the formulated model was applied to six extension channels (two factory based, two society-based and two agro-inputs dealer oriented extension channels) of the tea smallholding sector in the Matara and Ratnapura Districts. A survey was conducted using 180 randomly selected smallholders and primary data on their social status, extent cultivated, yield and other field data, inputs, source of information, degree of collaboration and type of extension activities were collected, Regular monitoring of extension activities of the participants in the selected channels was carried out for a period of 12 months. The satisfaction and perceptions of the services received from the specific extension channel was assessed by using scales. The primary and secondary evaluation data at different stages of implementation were statistically analysed using SPSS package. The results confirm the smallholder satisfaction on effectiveness of collaborative approach PPP model in all dimensions (Frequency, Adequacy, Usefulness, Relevancy and overall satisfaction). The level of perception on partnership significantly correlated with their exposure to extension activities $(p<0.001)$ and their commitment $(p<0.05)$ towards extension programs. The PPP extension model implemented in this study is proven as effective in all dimensions $(p<0.05)$. Hence, it is recommended that the organizations responsible develop management and fiscal procedures to adopt this model to better serve the smallholders.
\end{abstract}

Keywords: Collaborative approach, extension model, clientele satisfaction, public-private partnership, tea smallholdings

\section{INTRODUCTION}

The tea industry continues to occupy an important place in the economy of Sri Lanka. Tea industry provides employment to about two million people, which is $9.8 \%$ of the total population. The contribution of the tea sector to the Gross National Product (GNP) was $0.9 \%$ in 2015 . Tea plays a significant role by earning foreign exchange to the country. In 2015, 307

\footnotetext{
Department of Agricultural Extension, Faculty of Agriculture, University of Peradeniya, Sri Lanka

2 Department of Agricultural Economics and Extension, Faculty of Agriculture, University of Ruhuna, Sri Lanka

* Corresponding Author: lalithsenaka30@gmail.com
} 
$\mathrm{m} \mathrm{kg}$ of tea (93.4\% of total tea production of country) was exported, earning Rs.182billion (Central Bank, 2015).The adoption of recommended technologies of tea cultivation by tea small holder is essential. Even though the smallholder sector is the dominant and most important sector in country's tea production, its productivity has not reached the optimum level yet. According to the Tea Small Holding Development Authority (TSHDA) information, the average productivity of tea smallholder sector in low country is around 2100 $\mathrm{kg}$ per ha/yr (Tea Small Holdings Development Authority, 2013) which is far below its potential level of over $3000 \mathrm{~kg}$ per ha/yr (Tea Research Institute, 2002). The level of adoption of proven technologies related to cultural practices by tea smallholders is very low (Nathaniel, 1990; Mahaliyanaarchchi, 1996; Samaraweera et al.,2013). Lack of knowledge and non-availability of inputs at the required time were the major constraints in adopting technological innovations in the smallholding sector and which emphasized the importance of the effective extension services in this regard (Samaraweera et al.,2013). The dissemination of agricultural information to the smallholders in the very remote areas and also feedback of their suggestions to the research sector were found to be inadequate (Mahaliyanaarachchi, 1996; Karunadasa and Garforth, 1997;Samaraweeraet al.,2013). Research prioritization addressing the problems faced by the smallholders is very limited due to lack of effective monitoring and evaluation mechanism for the identification of smallholding problems (Mahaliyanaarachchi, 1996; Amarathunga and Wanigasundera, 2010).The technology dissemination system in the tea smallholdings sector has public and private parties operating through various channels for the transfer of technology. However, the public extension system in the tea sector is not expanding at the required rate to meet the increasing demand mainly due to financial constraints and inadequate manpower availability. Therefore, formal communication channels presently available between the Tea Research Institute (TRI) and tea smallholders are inadequate for the timely dissemination of tea technologies to reach all the tea smallholders in the island. In this context, a thorough understanding of the nature of these public and private extension channels and exploring the potentials to introduce a linking extension system of Public-Private Partnership (PPP) model is urgently required. This empirical study aims to reach such targets with following objectives.

\section{General objective}

This study aims to elucidate the potentials to introduce a PPP extension model by studying the factors affecting and appraising the partners' willingness for such an extension model for effective transfer of technologies to the tea smallholders as a remedy to fill the gap existing in the extension service to tea smallholders in Sri Lanka.

\section{Specific objectives}

Taking into consideration the factors and needs of the tea smallholdings sector, the present study attempts to achieve the above general objective through the following specific objectives were;

i. To introducea PPP extension model for tea smallholding sector in the low country.

ii. Toassess smallholders satisfaction on extension activities conducted by PPP Extension model.

iii. To assess theclienteleperception over the PPP Extension model. 
iv. To make recommendations for the establishment of an effective PPP extension model (s).

\section{Application of PPP extension model}

The partnership concept arose from the recognition that relationships between researchers, extension, farmers and industry, should be more actively integrated to develop effective extension programs (Rolling and Engel, 1991). PPPs are increasingly being emphasized as a mechanism for improving public service provision and implementing development programs. Conceptually, partnership is an extended form of group dynamics where two or more parties establish relationships and leverage resources to work together with the expectation that each of the parties would achieve greater goal than working individually (Morse, 1996). Having applied the above concept to technology dissemination process of tea smallholdings sector, all key partners have to be working together maintaining autonomy and independence, and also attain their individual goals together with those of the other stakeholders in the sector. Partnership provides opportunities for all partners to learn new competence. The partnership also makes information available about the methods of accessing and using resources effectively (Fehnel, 1995) (Fig. 1).

\section{Process of Partnership}

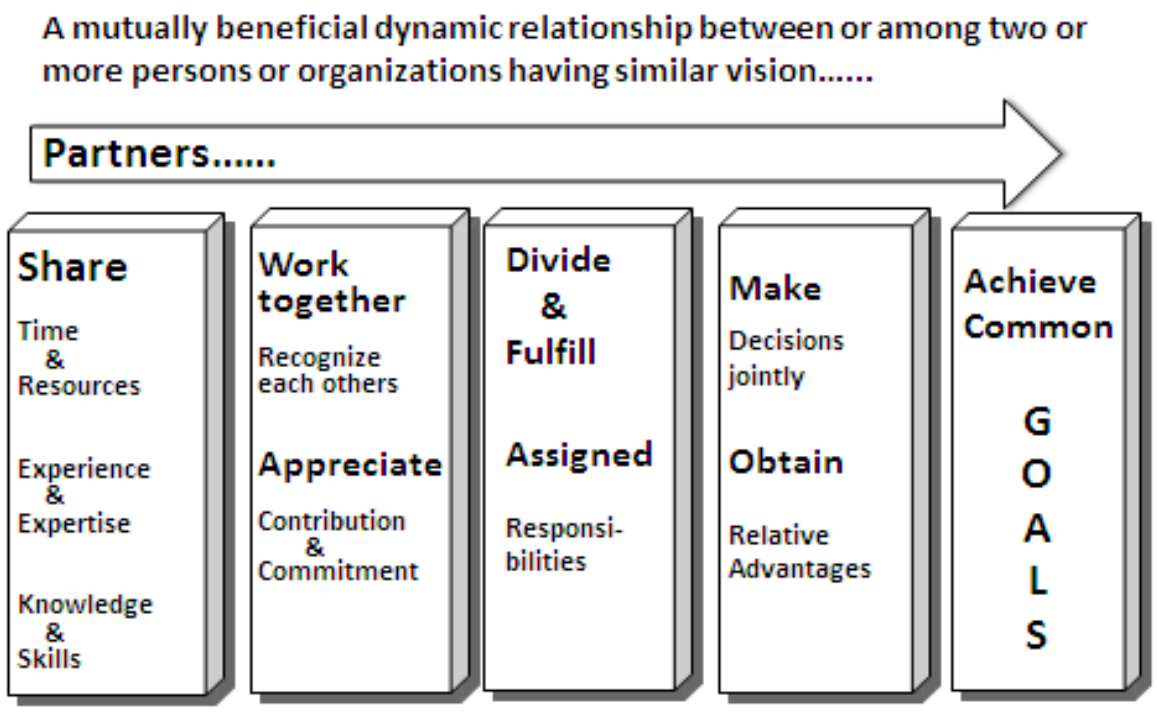

Fig. 1. Process of partnership

Partnership building efforts can both promote the initial creation of a partnership and enhance an existing partnership's functioning. For this study, a flexible and generic approach to partnership building was used, distinguishing six main phases such as;

i. Pre partnership phase:Identification of common interests space for building up partnership.

ii. Partnership initiationphase. 
iii. Partnership negotiation phase:Design of the partnership.

iv. Partnership implementation phase.

v. Partnership monitoring and evaluation phase:Achievements through partnership

vi. Post partnership phase:Termination, revision or extension of partnership model

Having considered the each step of the partnership building process, a PPP Model was developed to meet the objectives and requirements of the study (Fig. 2).

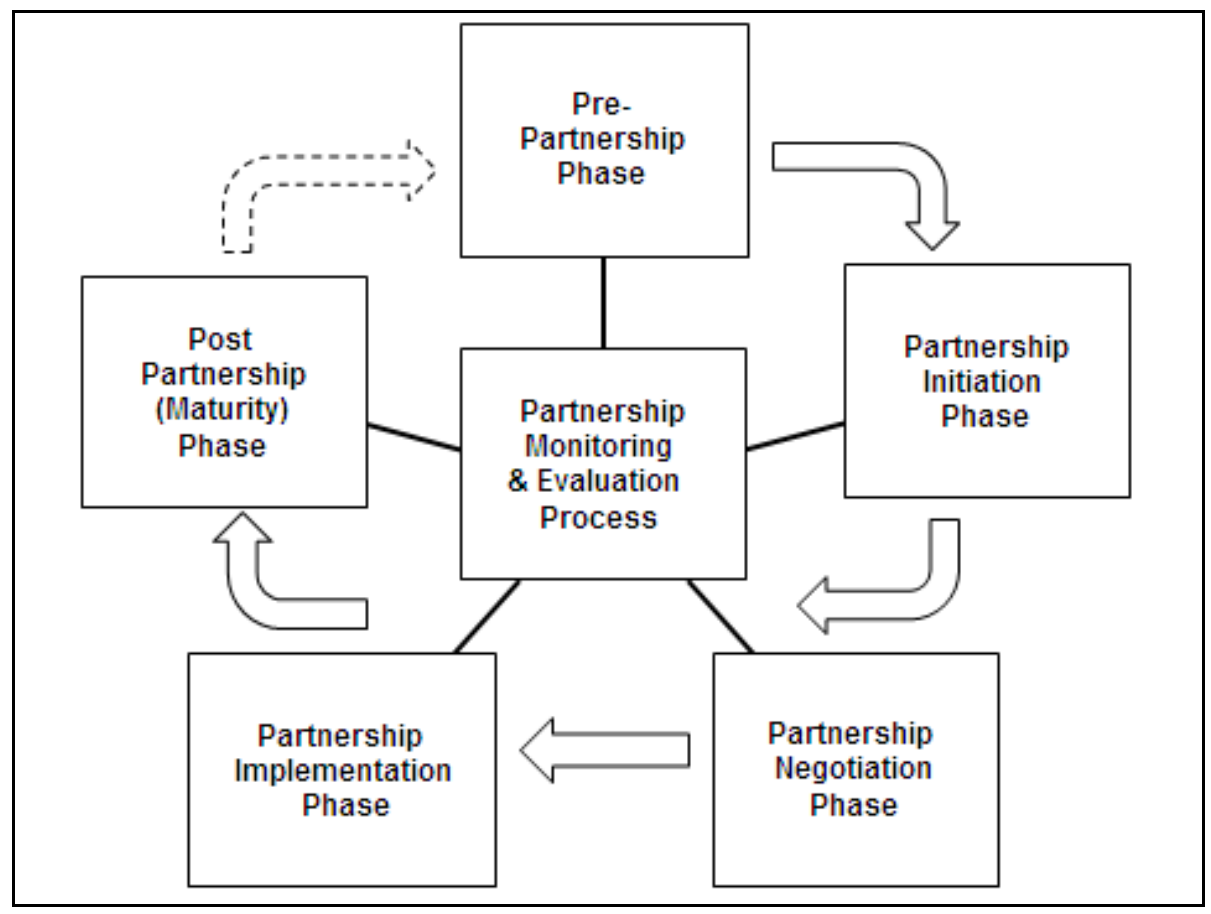

Fig. 2. Conceptual framework for process of public-private partnership

The research plan for the study was designed based on this broad framework. Research plan illustrates the activities scheduled for each phases of building process of PPP Extension Model.

\section{Formulation of PPP model for smallholding tea sector}

Based on the degree of collaboration and degree of perceived partnership between different stakeholders in the tea smallholder sectorexplained by the authors in the different stages of research process of this study (Amarathunga and Wanigasundera, 2010) and on the linking mechanism of partnership concept derived from the literature survey (Amarathunga, 2015), a PPP Model was developed for tea small holding sector in the low country. This model consists of three main Knowledge Systems viz. Knowledge, Generation, Dissemination and Utilization that require strong linking and feedback mechanisms (Fig. 3). 


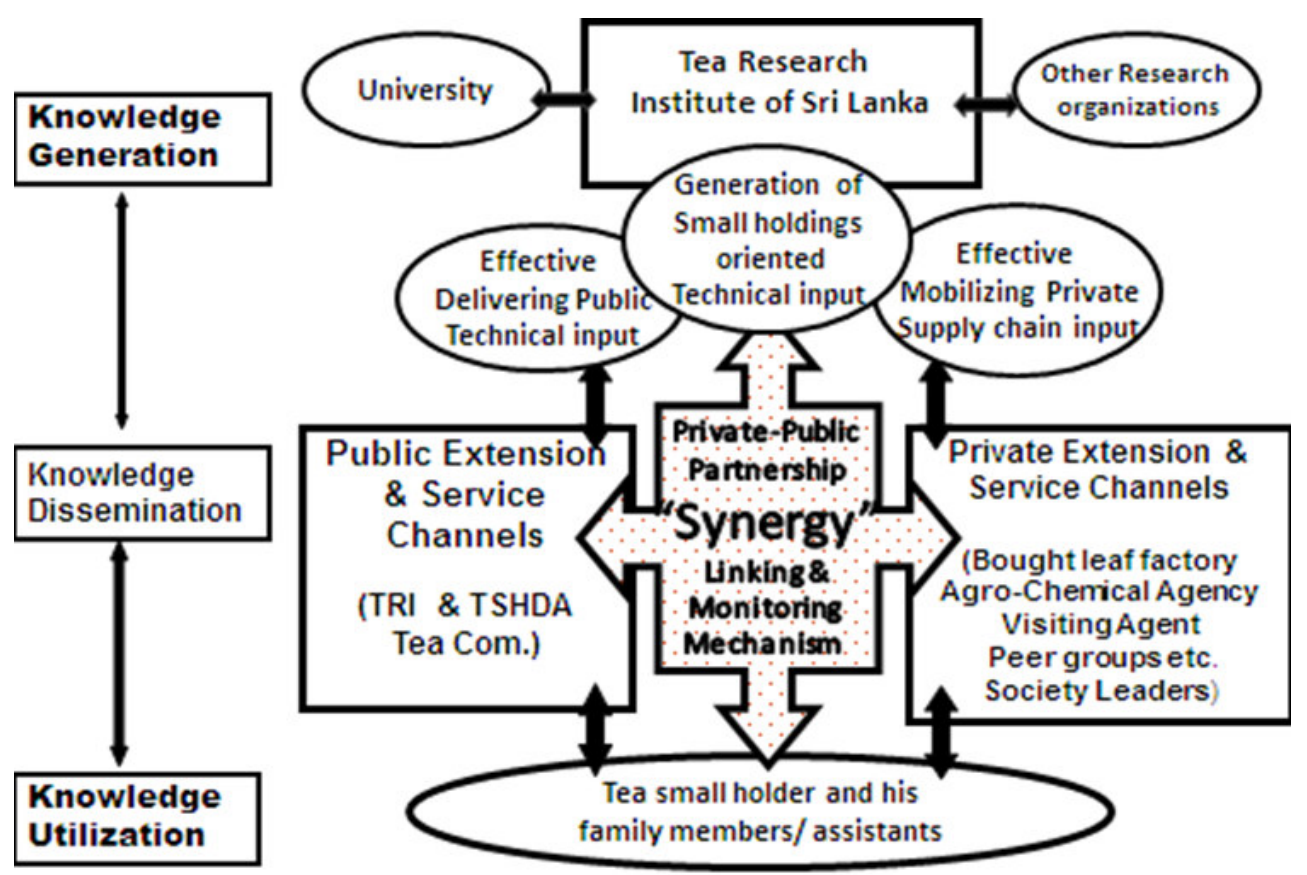

Fig. 3. Formulated model of PPP for the teasmallholding sector

This formulated PPP model (Fig. 3) consists of the main actors of the three main sub systems viz.KnowledgeGeneration, Dissemination, and Utilization operating in the areaand who were willing to develop a strong linking and feedback mechanism. The expectations of the proposed model were as follows;

i. Knowledge Generation System should initiate technology generation focusing smallholder specific problems and also conduct adaptive field trial at small holdings in different locations prior to releasing the recommendation.

ii. All partners belong to public and private sector in the technology dissemination process of tea smallholdings sector should have strong collaboration with each other and they would be willing to work together by sharing experience.

iii. Sharing resources while maintaining their autonomy and independence.

iv. In addition todissemination of technology, PPP extension service should proactively work-together for the distribution of inputs and services on time.

vii. Smallholders also should proactively participate in smallholder-specific technology generation by facilitation of field testing of new innovations in their lands and record keeping.

viii. The internally developed public and private monitoring mechanism with the representation of all partners will drive the system efficiently and effectively and reach the set targets within the scheduled time frame.

ix. With the active commitment and dedication of the all partners the developed mechanism was expected to facilitate efficient and effective technology dissemination process to smallholders whilst addressing their field problems most appropriately. 


\section{METHODOLOGY}

\section{Monitoring the implementation process of the formulated PPP Model}

The research planwas initiated to monitor the implementation process of the PPP Modelto ascertain the partners' willingness by assessing clientele satisfaction on PPP extension activities conducted by such an extension model and to make recommendations for the establishment of an effective PPP extension model(s) to ensure efficiency of technology transfer to low country tea smallholders.

\section{Selection of study locations}

Two key tea smallholdings districts in the low country, Matara and Ratnapuraserved by a variety of public and private extension and input services channels were selected for this empirical study. These districts consist of $17.02 \%$ and $24.67 \%$ of holdings included in the study respectively (Ministry of Plantations, 2013) (Fig. 4).

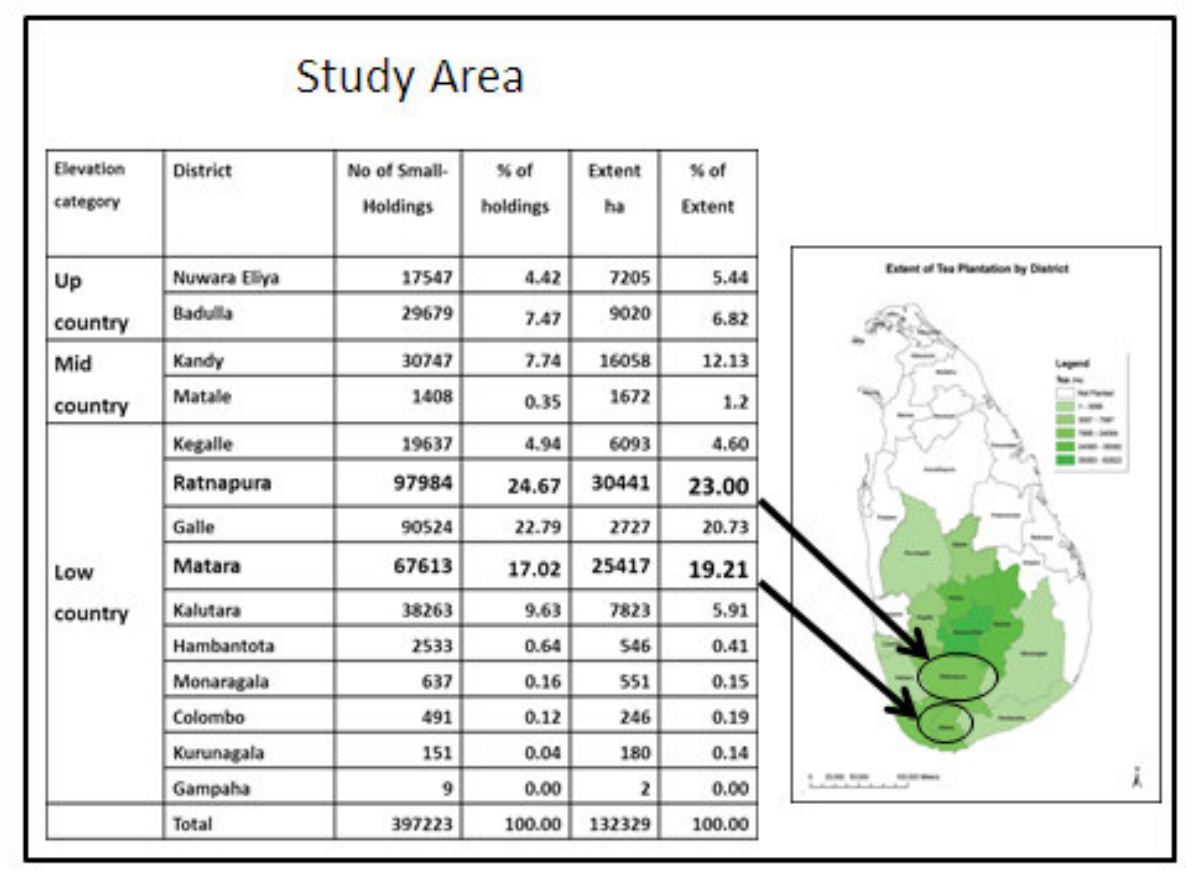

Fig. 4. Details of tea growing districts and study locations

\section{The research plan}

The research plan for the study was designed based on the conceptual frameworkof Partnership Process (Fig. 2). Research plan illustrates the activities scheduled for each phases of building process of the PPP Extension Model. 


\section{i. Pre-partnership stage}

\section{a) Selection of extension channels and PPP partnersand smallholders}

Having observed the collaborative involvement of extension activities in the tea smallholdings sector with the tea sector line institutes such TRI, TSHDA, Tea Commissioner's Division of Sri Lanka Tea Board (SLTB) and Tea smallholdings related societies during pre-testing stage, six extension channels including twofactory based extension channels, two society-based extension channelsvizTSHDA- Tea ShakthiSociety based formal extension channel and TRI -GemideriyaSociety based extension channeland two agro-inputs dealer oriented extension channels were selected for the study. Extension staff of each channel representing both public and private sectors and other stakeholders was also involved in this pilot project.Thirty smallholders per each extension channel were randomly selected for the detailed field study (Table 1).

Table 1. Extension channels selected for the implementation and monitoring of PPPExtension Model

\section{Type of extension channel}

\section{Type of partners}

Public sector Private sector

Tea factory based extension channels

1. Lumbini factory based partnership channel in Matara

Research \& $\quad$ Factory extension staff extension staff TRI/TSHDA TI/Tea

2. Folcon factory based extension Com. channel in Ratnapura

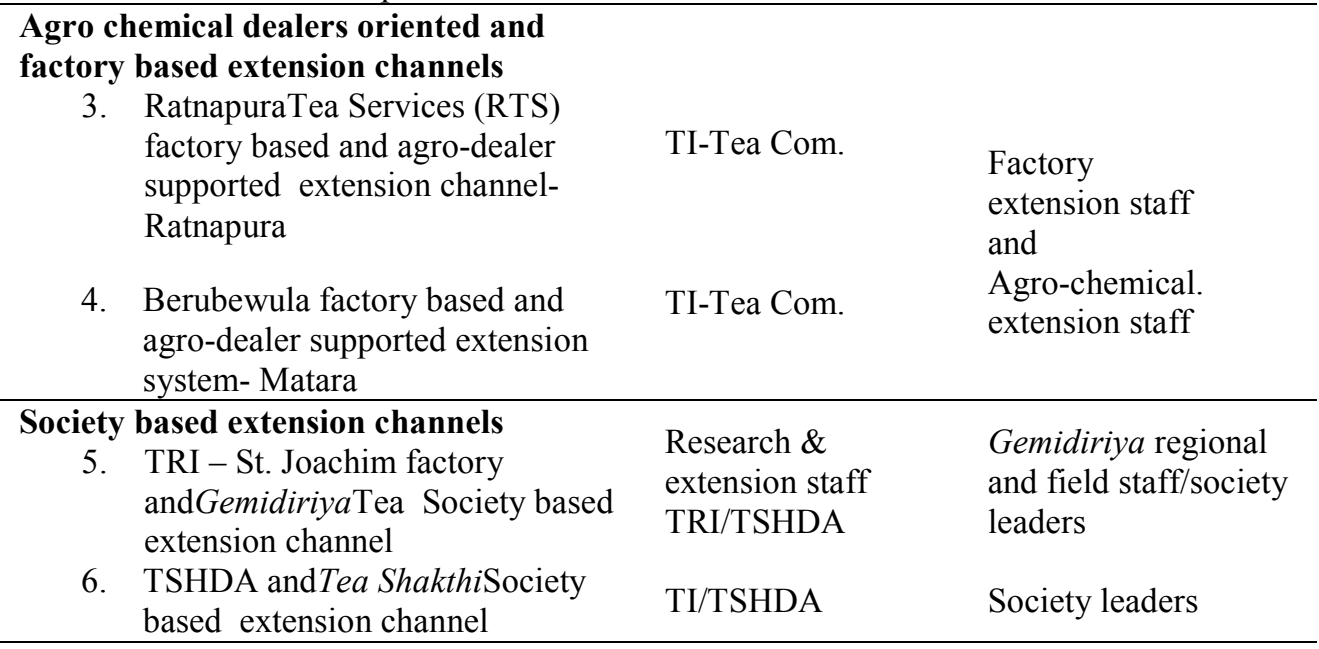

\section{b) Negotiation phase of partnership}

Partnership negotiation phase involved division of responsibilities. All stakeholders participated in the introductory season of the pilot project implementation stage were separated into different groups and each group was assigned to develop work plan and the list of responsibilities for each partners of the PPP process. This activity was initiated 
by following the PRA techniques explained by Chamber (1997). The work-plan and a list of responsibilities developed with the contribution of all partnersare presented in Table 2.

Table 2. Work plan and list of assigned extension activities

\begin{tabular}{|c|c|c|c|c|}
\hline & Extension activity & $\begin{array}{l}\text { Role of public } \\
\text { extension service }\end{array}$ & $\begin{array}{l}\text { Role of private } \\
\text { extension service } \\
\text { or agro- } \\
\text { chemical dealer }\end{array}$ & $\begin{array}{l}\text { Role of clientele } \\
\text { (Smallholders) }\end{array}$ \\
\hline 1. & $\begin{array}{l}\text { Conducting } \\
\text { collaborative } \\
\text { extension program } \\
\text { seminar/field days }\end{array}$ & $\begin{array}{l}\text { Technology } \\
\text { dissemination }\end{array}$ & $\begin{array}{l}\text { Organizing and } \\
\text { assist technology } \\
\text { delivering, Cost } \\
\text { bearing }\end{array}$ & $\begin{array}{l}\text { Active } \\
\text { participation and } \\
\text { sharing field } \\
\text { experience and } \\
\text { feed back }\end{array}$ \\
\hline 2. & $\begin{array}{l}\text { Maintaining method } \\
\text { and results } \\
\text { demonstration blocks }\end{array}$ & $\begin{array}{l}\text { Delivering } \\
\text { practical know- } \\
\text { how }\end{array}$ & $\begin{array}{l}\text { Coordinate and } \\
\text { feedback / bearing } \\
\text { of cost of inputs }\end{array}$ & $\begin{array}{l}\text { Adoption of learnt } \\
\text { technologies and } \\
\text { feed back }\end{array}$ \\
\hline 3. & $\begin{array}{l}\text { Preparation and } \\
\text { distribution of } \\
\text { extension materials }\end{array}$ & $\begin{array}{l}\text { Production of } \\
\text { Technical } \\
\text { materials }\end{array}$ & $\begin{array}{l}\text { Cost bearing and } \\
\text { distribution }\end{array}$ & $\begin{array}{l}\text { Sharing materials } \\
\text { with their } \\
\text { neighbors and } \\
\text { feedback }\end{array}$ \\
\hline 4. & $\begin{array}{l}\text { Distribution of } \\
\text { fertilizer agro- } \\
\text { chemical and others }\end{array}$ & $\begin{array}{l}\text { Addressing client } \\
\text { technical issues } \\
\text { by regular } \\
\text { monitoring }\end{array}$ & $\begin{array}{l}\text { Provide material } \\
\text { and on time }\end{array}$ & $\begin{array}{l}\text { Application on } \\
\text { time and feed back }\end{array}$ \\
\hline 5. & $\begin{array}{l}\text { Financial assistance } \\
\text { to field development }\end{array}$ & $\begin{array}{l}\text { Coordinating for } \\
\text { getting subsidy }\end{array}$ & $\begin{array}{l}\text { Coordination } \\
\text { loan facilities }\end{array}$ & $\begin{array}{l}\text { Invest for field } \\
\text { development and } \\
\text { recover on time }\end{array}$ \\
\hline 6. & $\begin{array}{l}\text { Supply of quality } \\
\text { planting materials }\end{array}$ & Monitoring & $\begin{array}{l}\text { Coordination the } \\
\text { distribution of } \\
\text { materials }\end{array}$ & $\begin{array}{l}\text { Planting on time } \\
\text { and feedback }\end{array}$ \\
\hline 7. & $\begin{array}{l}\text { Supply of raw } \\
\text { materials to factory }\end{array}$ & $\begin{array}{l}\text { Addressing } \\
\text { technical and } \\
\text { legal issues }\end{array}$ & $\begin{array}{l}\text { Coordinating } \\
\text { paymenton time }\end{array}$ & $\begin{array}{l}\text { Supply of quality } \\
\text { green leaf* }\end{array}$ \\
\hline
\end{tabular}

\section{ii) Implementation phase of PPP extension model}

Implementation was started with the signing of the partnership contract. Planned activities and commitments were then refined and agreed on, and the roles and responsibilities of the partners established. The concept of PPP approach and its work plan and monitoring mechanism were introduced to the key partners of the above extension channels during the introductory session of the pilot project. They agreed on the scope of the partnership extension program, configuring the partners' contributions in terms of conducting collaborative extension programs to small holding sectors. They also agreed to participate on the decision making structures and monitoring and feedback of day-to-day interactions once the partnership extension activities are operating. 


\section{iii) Monitoring and evaluation phase of partnership}

During monitoring stages, more collaborative extension activities with extension and management staff of above selected organizations were facilitated with invitations extended to public and private extension officer and coordinators to involve themselves with such activities. Research team regularly monitored the progress of all assigned extension activities, degree of commitment, contributions and collaborations during the conduct of extension activities. A pre-tested questionnaire was used for this purpose, coupled with visual observations as explained bySaravanan and Veerabhadraiah (2003) andHaqet al., (2006).

\section{iv) Datacollection}

Total of 180 smallholders were randomly selected on the basis of 30 smallholders per each channel.Additionally, necessary primary data about socio-economic status of tea smallholders, and their respective sources of information were collected from randomly selected 30 smallholders attached to each extension channel. Other necessary primary data about current status of the tea fields such as extent, age, bush stand and yield, sources of information and inputs and other materials,degree of collaboration and detail of type extension activities and other services offered by each extension channeletc. were collected. The selected smallholders were exposed to similar training program on the important field practices and provided inputs and other services through the relevant extension channels. Level of awareness and knowledge of smallholders on above field practices were assumed as same at the beginning of pilot project as similar training exposer was given through relevant extension channel. Required primary and secondary data mentioned above about smallholders and their tea lands, and also about extension organizations and their annual production targets and achievement in relation to extension activities were also recorded before and after establishment of PPP model. All public and private extension partners working in different extension channels were assigned to do planned extension activities and other list of duties, and also to take responsibilities as per the work plan reported in the Table 2 during the implementation and monitoring period of pilot project.

\section{Process level analysis on clientele satisfaction towards services of the PPP model}

The client satisfaction level was operationalized as the degree of satisfaction of the client with respect to number of extension programs conducted, extension visits done for problem solving, input supplying, printed advisory leaflet/ pamphlets distributed etc. made by PPP extension personnel to their clientele. Frequency, adequacy, usefulness and, relevance of servicers offered by the PPP channels were also measured before and after introducing the PPP model. A client satisfaction inventory was developed based on relevant literature (Ray (1998); Saravanan and Veerabhadraiah (2003); Mahaliyanaarchchi (2005); Mahaliyanaarachchi et al. (2006); Sidhakaran (2010) and experts opinion). Responses of clientele were obtained on five points continuum with the scores (some extent - 1 , belowaverage extent -2 , average extent -3 , above average extent -4 and high extent -5 ). The data collected from six relevant extension channels were pooled and analysed item- wise responses at the beginning $\left(1^{\text {st }}\right.$ stage $)$ and 12 months after establishment of PPP $\left(2^{\text {nd }}\right.$ stage $)$. Mean value for above parameters were worked out and mean comparison for each couple of data set collected at above mentioned two stages were separately analysed by application of t-test using SPSS statistical program. 


\section{The perception of smallholder over the PPP model}

Scoring system was developed to measure the smallholders' perception on PPP model before and 12 months after implementation of same. Smallholder's response was collected during focus group discussions held at beginning and 12 months after implementation of PPP at each extension channel. Smallholders responses were collected based on prepared eight statements for strengthening of PPP model to be marked on smallholder's preference as explained by Saravanan and Veerabhadraiah (2003), Mahaliyanaarchchi (2005), Mahaliyanaarachchiet al. (2006), Haqet al. (2009) andSidhakaran (2010). Responses on degree of perception of smallholders was measured using five points scale (some extent 1 , belowaverage extent- 2 , average extent- 3 , above average extent -4 and high extent -5 ). The collected relevant data from six extension channels on degree of perception on overall activities of PPP were measured for all extension channels by obtaining item-wise responses for beginning ( $1^{\text {st }}$ stage $)$ and 12 months after establishment of PPP $\left(2^{\text {nd }}\right.$ stage $)$. Mean value for above parameters were worked out and mean comparison for each couple of data set collected at above mentioned two stages were separately analysed by application of t-test using SPSS statistical program.

\section{RESULTS AND DISCUSSION}

\section{Smallholders' satisfaction on outcomes of extension activities conducted by PPP Model}

The collected data were pooled and analysis was done item- wise responses at the beginning $\left(1^{\text {st }}\right.$ stage $)$ and 12 months after the establishment of PPP $\left(2^{\text {nd }}\right.$ stage $)$.

Table 3. Smallholders' satisfaction on frequency of extension activities ofthe PPP Model

\begin{tabular}{|c|c|c|c|c|c|c|c|}
\hline \multirow{3}{*}{$\begin{array}{l}\text { Frequency of extension } \\
\text { activity } \\
\text { Distribution of advisory } \\
\text { leaflet, handout }\end{array}$} & \multicolumn{3}{|c|}{ Beginning of PPP } & \multicolumn{3}{|c|}{ After PPP } & \multirow{2}{*}{$\begin{array}{c}\text { T } \\
\text { value }\end{array}$} \\
\hline & Mean & SD & Rank & Mean & SD & Rank & \\
\hline & 2.25 & 1.33 & 4 & 3.28 & 1.14 & 3 & $12.34 *$ \\
\hline Extension programs ${ }^{1}$ & 2.31 & 1.27 & 3 & 3.37 & 1.36 & 2 & $11.31 *$ \\
\hline Supply of inputs ${ }^{2}$ & 2.46 & 1.06 & 2 & 3.20 & 1.29 & 4 & $12.82 *$ \\
\hline $\begin{array}{l}\text { Extension visit for } \\
\text { advising and problem } \\
\text { *Significant atp }<0.05\end{array}$ & 3.12 & 1.26 & 1 & 3.68 & 1.37 & 1 & $9.42 *$ \\
\hline
\end{tabular}

Table 3 shows the mean values of smallholder's satisfaction on frequency of plannedextension activities conducted during the study period with the collaboration of all partners for problem solving, technology dissemination and input distribution. Degree of satisfaction was measured in a five point scale. Results show that the degree of smallholder's satisfaction on frequency of extension programs conducted increased significantly for all extension activities during the study period at $\mathrm{p}<0.05$ level. In addition, mean values of smallholder's preferences were ranked. Highest preference with a mean 
value of 3.12 at the beginning and a mean of 3.68 at the $2^{\text {nd }}$ stage confirms that smallholders were highly satisfied at both stages about the frequency of advisory visits conducted by PPP extension staff for problem solving. The results also confirm that smallholders seek more frequent individual visits to their fieldsfor problem solving and advising at both stages. The $2^{\text {nd }}$ and $3^{\text {rd }}$ preferences at the beginning of PPP, with mean values of 2.46 and 2.31 , respectivelywere for frequency of inputs supply and frequency of extension programs for technology transfer and training purposes. The $2^{\text {nd }}$ and $3^{\text {rd }}$ preferences recorded twelve months after introducing PPP model, with mean values of 3.37 and 3.28, respectively were for frequency of extension programs conducted for technology transfer and distribution of technical materials such as leaflets etc.

Table 4. Smallholders' satisfaction on adequacy of activities of the PPP Model

\begin{tabular}{|c|c|c|c|c|c|c|c|}
\hline \multirow{2}{*}{$\begin{array}{l}\text { Adequacy of extension } \\
\text { activity }\end{array}$} & \multicolumn{3}{|c|}{ Beginning PPP } & \multicolumn{3}{|c|}{ After PPP } & \multirow[t]{2}{*}{ T value } \\
\hline & Mean & SD & Rank & Mean & SD & Rank & \\
\hline $\begin{array}{l}\text { Distribution of advisory } \\
\text { leaflet, handout }\end{array}$ & 2.38 & 1.12 & 2 & 3.53 & 1.37 & 1 & $14.64 *$ \\
\hline Extension programs & 1.76 & 1.02 & 3 & 3.02 & 1.06 & 4 & $18.78^{*}$ \\
\hline Supply of inputs & 1.74 & 1.09 & 4 & 3.23 & 1.15 & 3 & $21.46^{* *}$ \\
\hline $\begin{array}{l}\text { Extension visit for } \\
\text { advising and problem }\end{array}$ & 2.44 & 1.18 & 1 & 3.27 & 1.23 & 2 & $10.87^{*}$ \\
\hline
\end{tabular}

*Significant atp $<0.05^{* *}$ Significant at $p<0.001$ level

The mean values of smallholder's satisfaction on adequacy of planned above extension activities conducted with the collaboration of all PPP extension partners during study period for problem solving, technology dissemination and input distribution are given in Table 4.The degree of satisfaction was measured in five point scale and mean value of adequacy related to extension activities were compared separately at the beginning of PPP and twelve months after implementation of PPP. Results show that the degree of smallholder's satisfaction on adequacy of all extension programs conducted during the study period significantly increased at $\mathrm{p}<0.05$ and at $\mathrm{p}<0.001$ levels.

Smallholders' preferences were also ranked according to the mean value at the two stages. Results show that smallholders were highly satisfied at the beginning (1st stage) on the adequacy of advisory visits conducted by PPP extension staff for problem solving. This extension activity, with a mean value of 2.44 ranked first, followed by adequacy on distribution of technical materials and extension programmes conducted ranked $2^{\text {nd }}$ and $3^{\text {rd }}$ with means of 3.38 and 1.76, respectively. At $2^{\text {nd }}$ stage, smallholder's recorded highest preferences on adequacy on distribution of technical materials, with a mean of 3.53 , followed by adequacy of extension visits by PPP extension staff with mean value of 3.27 , and supply of inputs with mean value of 3.23 , respectively.

Table 5 shows the mean values for smallholder satisfaction on usefulness of extension activities conducted with the collaboration of all PPP extension partners during the study period for problem solving, technology dissemination and input distribution. Degree of 
satisfaction was measured in a five point scale and mean values of usefulness related to extension activities at the beginning and twelve months after implementation of PPP were compared. Results show that degree of smallholder's satisfaction on usefulness of extension program conducted increasedsignificantly for all extension activities during the study period at $p<0.05$ and $p<0.001$ levels. Smallholder preferences were also ranked according the mean value west at both stages.

Table 5. Smallholders' satisfaction on usefulness ofextensionactivities of the PPP Model

\begin{tabular}{|c|c|c|c|c|c|c|c|}
\hline \multirow{2}{*}{$\begin{array}{l}\text { Usefulness of extension } \\
\text { activities }\end{array}$} & \multicolumn{4}{|c|}{ Beginning PPP } & \multicolumn{2}{|c|}{ After PPP } & \multirow{2}{*}{$\begin{array}{c}\mathrm{T} \\
\text { value }\end{array}$} \\
\hline & Mean & SD & Rank & Mean & SD & Rank & \\
\hline $\begin{array}{l}\text { Distribution of advisory } \\
\text { leaflet, handout }\end{array}$ & 2.36 & 1.22 & 1 & 3.29 & 1.34 & 2 & $09.46^{*}$ \\
\hline Extension programs & 1.43 & 0.94 & 3 & 3.14 & 1.14 & 3 & $24.32 * *$ \\
\hline Supply of inputs & 1.38 & 1.10 & 4 & 1.57 & 1.32 & 4 & $02.43^{*}$ \\
\hline $\begin{array}{l}\text { Extension visit for } \\
\text { advising and problem } \\
\text { solving }\end{array}$ & 1.88 & 1.18 & 2 & 3.34 & 1.18 & 1 & $19.12 * *$ \\
\hline
\end{tabular}

Results show that smallholders were highly satisfied at the beginning on the usefulness of distribution of extension materials by PPP extension staff. With a mean value of 2.36 , this extension activity scored the highest preference at the beginning, followed by usefulness on distribution of technical materials and extension programs ranked $2^{\text {nd }}$ and $3^{\text {rd }}$ preference with mean values of 1.88 and 1.43 , respectively. After 12 months, smallholders reported highest preferences on usefulness as extension visits made by PPP extension staff with mean of 3.34. This was followed by distribution of leaflets by PPP extension staff and supply of inputs, with mean values of 3.29 and 3.14 , respectively.

Table 6. Smallholders' satisfaction on relevance of extension activitiesof PPP Model

\begin{tabular}{|c|c|c|c|c|c|c|c|}
\hline \multirow{2}{*}{$\begin{array}{l}\text { Relevance of Extension } \\
\text { activities }\end{array}$} & \multicolumn{3}{|c|}{ Beginning PPP } & \multicolumn{3}{|c|}{ After PPP } & \multirow[t]{2}{*}{ T value } \\
\hline & Mean & SD & Rank & Mean & SD & Rank & \\
\hline $\begin{array}{l}\text { Distribution of advisory } \\
\text { leaflet, handout }\end{array}$ & 1.78 & 1.05 & 4 & 3.68 & 1.26 & 3 & $24.22 * *$ \\
\hline Extension programs & 1.98 & 0.69 & 3 & 3.31 & 1.17 & 4 & $20.98 * *$ \\
\hline Supply of inputs & 2.21 & 1.18 & 2 & 3.82 & 1.11 & 2 & $21.92 * *$ \\
\hline $\begin{array}{l}\text { Extension visit for } \\
\text { advising and problem } \\
\text { solving }\end{array}$ & 2.26 & 1.14 & 1 & 4.12 & 1.18 & 1 & $19.34 * *$ \\
\hline
\end{tabular}


Table 6 presents the mean values of smallholder satisfaction on relevancy of extension activities conducted with the collaboration of all PPP extension partners during the study period for problem solving, technology dissemination, and input distribution. Degree of satisfaction was measured in five point scale and the mean value of relevancy relating to extension activities at the beginning of PPP and twelve months after implementation of PPP were compared. Results show that degree of smallholder's satisfaction on relevancy of extension program conducted increased significantly for all extension programs during the study period at $\mathrm{p}<0.001$ level. The mean values for smallholder preferences at the two stageswere also ranked. Results show that smallholders were highly satisfied at the beginning on the relevancy of distribution of extension materials by PPP extension staff, reporting highest preference with a mean of 2.26, followed by distribution of technical materials and extension programs conducted with means of 2.21 and 1.98 , respectively. At the $2^{\text {nd }}$ stage, smallholder's highest preference on relevance, with a mean of 4.12 was extension visits made by PPP extension staff. This was followed by extension visit by PPP extension staff with a mean value of 3.82 and supply of inputs with mean value 3.68 , respectively.

\section{Smallholders' Perception of the PPP Model}

The collected data were pooled and item- wise responses were analysed at the beginning $\left(1^{\text {st }}\right.$ stage) and 12 months after establishment of PPP ( $2^{\text {nd }}$ stage $)$.

Table 7. Smallholders'perception of the PPP Model

\begin{tabular}{|c|c|c|c|c|c|c|c|}
\hline \multirow{2}{*}{ Smallholders perception } & \multicolumn{3}{|c|}{ Beginning of PPP } & \multicolumn{3}{|c|}{ After PPP } & \multirow[t]{2}{*}{ t value } \\
\hline & Mean & SD & Rank & Mean & SD & Rank & \\
\hline $\begin{array}{l}\text { Regularity of visit to } \\
\text { smallholder land }\end{array}$ & 1.64 & 0.94 & 8 & 3.31 & 1.09 & 7 & $23.20 * *$ \\
\hline $\begin{array}{l}\text { PPP-Extension } \\
\text { Offerstechnologybestfitted } \\
\text { tothe smallholders' land }\end{array}$ & 2.25 & 1.24 & 6 & 3.48 & 1.44 & 2 & $13.08^{*}$ \\
\hline $\begin{array}{l}\text { Timelyavailabilityof PPP } \\
\text { extensionservices }\end{array}$ & 2.44 & 1.12 & 4 & 3.36 & 1.24 & 5 & $16.16^{*}$ \\
\hline $\begin{array}{l}\text { Satisfaction withthe PPP- } \\
\text { extensionteaching } \\
\text { methods }\end{array}$ & 3.05 & 1.22 & 2 & 3.41 & 1.16 & 4 & $5.14 *$ \\
\hline $\begin{array}{l}\text { Effective } \\
\text { deliveringextensionmessa }\end{array}$ & 3.09 & 1.28 & 1 & 3.45 & 1.15 & 3 & $5.41 *$ \\
\hline $\begin{array}{l}\text { Timely delivering of } \\
\text { fertilizer and other inputs } \\
\text { on time }\end{array}$ & 2.94 & 1.10 & 3 & 3.32 & $\begin{array}{c}1.14 \\
5\end{array}$ & 6 & $5.20^{*}$ \\
\hline $\begin{array}{l}\text { Encourage to maintain } \\
\text { quality of leaf standard } \\
\text { and to reach high rate }\end{array}$ & 2.42 & 1.04 & 5 & 2.89 & 1.13 & 8 & $6.206^{*}$ \\
\hline $\begin{array}{l}\text { Increase tea field } \\
\text { productivity }\end{array}$ & 2.13 & 1.18 & 7 & 3.49 & 1.04 & 1 & $21.98 * *$ \\
\hline
\end{tabular}


Table 7 shows smallholders responses on prepared eight statements for strengthening of PPP model. T- test was used to compare mean values for perception over the eight factors measured at the beginning of the introduction of the PPP model and 12 months after.

As shown in Table 7, there was a significant improvement in the perception of all parameters over the 12 month study period at $\mathrm{p}<0.05$ and $\mathrm{p}<0.001$ levels. Ranking of the mean values of perception at the beginning and 12 months after introduction of the PPP model shows that at the beginning of the introduction of PPP, smallholders expressed highest rate of perception over effectiveness of messages delivery by all extension channels (Factory, Factory + Agro Agent or society based), with a mean of 3.09, followed by way of conducting extension programs and way of delivering inputs ranked $2^{\text {nd }}$ and $3^{\text {rd }}$ with means of 3.05 and 2.94, respectively. After 12 months of operation of the PPP model, smallholder's expressed highest rates of perception over the "impact of PPP on productivity improvement", recording a mean value of 3.49 , followed by technology best fitted to small holding land and effectiveness of delivering message ranked $2^{\text {nd }}$ and $3^{\text {rd }}$ with means of 3.48 and 3.45 , respectively.

The initial positive impressions of smallholders about technology transfer and inputs delivery as major advantages of the collaborative effort in the PPP model is due to their concerns previously about inputs collection from all sources. At the $2^{\text {nd }}$ stage, they have considered productivity improvement as the biggest benefit of the PPP model, and effectiveness of PPP extension activities (best fitted) the second most valuable. The level of perception on partnership significantly correlated with the stakeholder's exposure to extension activities $(p<0.001)$ and their commitment $(p<0.05)$ in organizing such extension programs. These results confirm the smallholder perception on effectiveness of collaborative approach PPP model in all dimensions.

\section{CONCLUSIONS}

- By implementation and monitoring of Modified PPP Model for six extension channels confirmed that tea smallholders have expressed significantly positive satisfaction on PPP extension activities directed by Modified PPP model in all dimensions (Frequency, Adequacy, Usefulness andRelevancy).

- The initial positive impressions of smallholders about technology transfer and inputs delivery as major advantages of the collaborative effort in the PPP model is due to their concerns previously about inputs collection from all sources.

- At the 2nd stage, they have considered productivity improvement as the most significant benefit of the PPP model and relevance of PPP extension activities (best fitted) as the second most valuable benefit. These results confirm the smallholder perception on positively on the effectiveness of collaborative approach of PPP model in all dimensions.

\section{Recommendations for the establishment of an effective PPP model for tea smallholding sector in the low country}

The PPP model is now emerging as a possible solution to the problems related to effective technology transfer. This is in response to the issues associated with the supply-driven, top- 
down approach to extension with excessive state intervention aimed at attaining equity with growth. The PPP extension model developed in this study (Fig. 3) is proven as effective. However, so far this model is practiced by only a handful of stakeholders and locations.

- Hence it is recommended that the organizations responsible for developingthe management and fiscal procedures to adopt this model and striveto serve all smallholders through such models.

- Such a partnership mechanism could be the most effective way of disseminating tea related technologies to tea smallholders than the individual efforts of the public institutions (TRI, TSHDA), the market oriented (fertilizer or agrochemical agencies) or bought leaf factories.

- In order to achieve a greater interaction among key stakeholders and their proactive participation in planning, implementation and monitoring of the partnership programs, cooperation between staff of partners, support from community leadership, mutual respect, appreciation of the contribution of partners and effective communication are of paramount importance in implementing an effective partnerships extension system.

\section{ACKNOWLEDGEMENT}

The authors are grateful to the Director, Extension and Research staff of Tea Research Institute, regional staff of Tea Small Holdings Development Authority, regional staff of Tea Commissioner's Division in Ratnapura and Matara, Director and staff of People's company of Gemidiriya and GamanagumaFoundation (PCGG) and staff of RTS, Lumbini and Berubewula tea factories and extension staff of CICAgri Business and A. Baur\& Co. Ltd and to the members of Tea smallholder societies for their support.

\section{REFERENCES}

Amarathunga, M.K.S.L.D. (2015). Development of a Public-Private Partnership Extension Model for Effective Dissemination of Tea Technologies with special reference to the low country Tea Smallholdings sector in Sri Lanka, Ph. D Thesis, Postgraduate Institute of Agriculture, University of Peradeniya, Sri Lanka (un published.), 222-224.

Amarathunga, M.K.S.L.D. andWanigasundera, W.A.D.P. (2010). Strengthening Links among the Key Stakeholders of Public-Private Partnership Extension Approach: Lessons Leant from Tea Smallholding Sector in Sri Lanka, Sri Lanka Journal of Tea Science, Vol 75. (1), 1-16.

Central Bank Annual Report (2015).Central Bank of Sri Lanka, Colombo, Sri Lanka [on line].Availat https://www.cbsl.gov.lk/../annual_report/ar2015e/ar08_content_2015

Chambers, R. (1997). Whose Reality Counts? Putting the First Last Intermediate Technology Publications, London, 1997, p. 106.

Fehnel, R. (1995). The importance of partnership. (online). Available at http://ncsap.ncup.org/fehnel.htm. 
Haq, I.U., Ahmad, M., Ali,T. and. Zafar, M.I. (2009). An Analysis of Farm Services Centre (FSC) Approach Launched for Agricultural Extension in NWFP, Pakistan. Pak. J. Agric. Sci. 46(1), $69-72$.

Karunadasa, K. and Garforth, C. (1997). Adoption Behaviour in Smallholder and Estate Tea Sectors in Relation to Selected Innovations: A Comparative Study in Sri Lanka, Journal of Extension Systems, 13(1\& 2):70-82. [on line] Available at http.//www.jesonline.org/1997v13htm.

Mahaliyanaarchchi, R.P. (1996). Dissemination information to the tea smallholders in Sri Lanka, Ph. D Thesis, Postgraduate Institute of Agriculture, University of Peradeniya, Sri Lanka (unpublished).

Mahaliyanaarchchi R.P. (2005). Attitudes of Agricultural Scientists, Extension Personnel and Farmers Towards commercialization of the Agricultural Extension Service: A Study in Sri Lanka, Beraterinnen News, Vol 1, 47-51.

Mahaliyanaarachchi, R.P., Wijeratne, A.W. and Bandara, R.M.A.S. (2006), Developing an attitudinal scale to measure the attitudes of the farmers towards commercialization of agricultural extension, The Journal of Agricultural Sciences, vol.2, no.3,26-35.

Morse, S.W. (1996). Building collaborative communities.Leadership Collaboration Series.Pew Partnership.[Online]. Available at: http://www.pew-partnership. org/research/ics/ collabindex.html.

Ministry of Plantation Industries (2013), Plantation sector statistical pocket book, Colombo.88-89.

Nathaniel, R.K. (1990). Interim report of sample survey of qualitative aspects of tea smallholdings in Sri Lanka, Tea Small Holding Development Authority, Colombo (unpublished.).

Rolling, N. and Engel, P.G.H. (1991), 'The development of the concept of AKIS: implications for extension', In: Agricultural Extension: Worldwide Institutional Evolution and Forces for Change, Rural Development, World Bank.

Samaraweera G.C., Qing Ping and Li Yanjun (2013). Promoting tea business in the tea smallholding sector in developing countries through efficient technology transfer system: Special reference to Sri Lanka, African Journal of Business Management Vol. 7(22), 21862194.

Saravanan, R. and Veerabahadraiah, V. (2003) Public and Private Extension: Changing Objectives, presented in the National Seminar on Extension Strategy for Promoting Development Initiatives among Farming Community, $\left(18^{\text {th }}-20^{\text {th }}\right.$ June, 2003) G.B. Pant University of Agriculture and Technology, Pant Nagar, Urranchal, India.

Sidhakaran, V.S. (2010) Awareness, Knowledge and Adoption of Agricultural Technologies by the Corporate Tea Sector in Sri Lanka, "Sri Lanka Journal of Tea Science, Vol 75, p 2, 4661. 
Tea Research Institute of Sri Lanka (2002).Technical Report for 2002.Tea VP cultivar recommendations for low country - Tea Research Institute, Talawakelle, 42-44.

Tea Research Institute of Sri Lanka (2003).Advisory circular No.HP 2 - Guidelines on plucking, 1-5.

Tea Smallholdings Development Authority (2013) Annual report for the year -2013, Colombo. 5-7. 